\title{
Research on High Quality Course Construction of Human Resource Management
}

\author{
Hai-Liang MA ${ }^{a}$, Wen-Qin $\mathrm{LI}^{\mathrm{b}}$, Meng-Ge $\mathrm{LI}^{\mathrm{c}}$ \\ Administration School, Hohai University, Chang Zhou, China \\ amahlpaper@163.com, ${ }^{\mathrm{b}}$ liwq@hhuc.educ, ${ }^{\mathrm{c}}$ limg@hhuc.edu.cn
}

Keywords: adult education, high quality courses ,human resource management, course design, course reform

\begin{abstract}
The course construction of adult education is an important link for improving the quality, and it is also the important points of adult education construction and reform. In the process of building curriculum group and professional brand, Adult education construction plays a important role. At the same time, it promote the formation of running a distinctive school. The teaching team, teaching methods, teaching materials, teaching content and teaching management system need to be considered during the construction of high quality courses, so as to establish effective teaching, demonstrative courses.
\end{abstract}

\section{Introduction}

Excellent course construction is the foundation of professional construction and a key element of improving teaching level for high education. And it also plays an important role in establishing a good image and refreshing theirselves for the education department. In 2003, the Ministry of Education officially started the college courses construction. In the next few years, the Ministry of education has issued relevant documents and regulate the process of excellent courses construction. Aimed at the full implementation, the quality of undergraduate teaching and teaching reform project was published in 2007(referred to as the "quality project") .It emphasis the need to select some excellent courses, then comprehensively improve the level of construction and teaching quality by the reform and construction of the courses. The documents also proposed to create a teaching team to build an effective cooperation mechanism, so as to promote the reform of teaching content and methods. Since the implementation of the project, Quality Project accelerate the construction and teaching reform in college course. Adult education course also has a vital role in improving the quality of adult education. Human resources management course is evaluated as excellent course by Hohai University adult education department in 2012 and requested to carry out quality project ulteriorly in the next three years. In this context,it is particularly necessary to research on excellent courses construction of human resource management.

\section{The connotation and the function of adult education courses}

Excellent course construction has important significance as the an important part of "quality project" of Ministry of education.Liquan Liu made a systematic study about the connotation of quality course[1], he summarized the meaning of course from the perspective of curriculum elements, course orientation and curriculum characteristics. From the curriculum elements, excellent course construction is based on modern teaching contents ,modern information technology and scientific management system. And it is a overall construction in a set of concept, teaching, technology, method and system; from the position of curriculum, curriculum is distinctive and exemplary and it has outstanding teaching level;from the course characteristics, quality course is provided with the first-class teachers, first-class teaching contents, first-class teaching methods, first-class teaching materials and first-class teaching management.

The connotation of adult education courses is an excellent course which has decided that it must 
have the characteristics as mentioned above. So it can not be confused with the ordinary courses, it should play a leading role in the construction of courses. Secondly its teaching objects are the adult students who are usually busy with work so that they just can be engaged in theoretical courses in spare time.Therefore,that leads to a wide range of adjustment in teaching methods, teaching contents and teaching materials according to the actual situation. Therefore, adult courses are a good curriculum with adult characteristics and first-class teaching level.Construction of excellent course adult should reflect the modern adult education thought and be conductive with the general law of adult education. Also the curriculum construction should have distinct characteristics and apply modern teaching technology and method ,only by this can the adult education course play a positive role.

Construction of teaching courses influences on, not only the development of the course, but also the specialty and subject construction and the development of the college and the situation of adult education . In general, adult education courses mainly have the following functions. It can drive the curriculum group construction and development of reform. In this sense, the construction is not isolated, it's usually related to other professionals. On the one hand, the construction is often a long historical process, and in the process of its development, a wealth of teaching research and teaching reform experience can be accumulated and used as a paradigm for other curriculum. On the other hand,high quality courses are closely related to other courses, so it tend to drive the development of other courses construction.For example, HRM is a interdisciplinary subject composed of multidiscipline knowledge, involving Management,Phycology ,Organizational Behavior ,Statistic and Sociology etc. Thereby the subject interaction and mutual improvement are needed to achieve common development .It can promote the construction and development of brand professional. To get social recognition and ensure good enrollment rate, a brand course with favorable reputation is needed .Therefore,professional brand construction is also a pivotal element for the current adult education reform and development.On the one hand,the construction of excellent courses have further prospect for cultivation of talents; on the other hand,its development rely on the construction of high quality courses. High quality courses generally have higher theoretical value and practical value which can support a professional quality construction [2]. From the background and trend of enterprise management, HRM analyzes a series of problems including human resource planning, job analysis,recruitment, human resources training, performance assessment, compensation and benefits, labor relations and so on using the tools of Economics and Management.As a main line of business management,the construction of HRM courses generally tend to promote business management to become a professional brand.

\section{The content of adult education course}

\section{The construction of teaching team}

The key to teach the course construction is the construction of teaching team.In recent years, as rapid economic development of our country,adult higher education is developing rapidly, but the construction of teaching team construction and the inputs of experimental equipment are relative lag, this certainly will cause the decline of teaching quality. High-class teachers are the premise of excellent course, so it requires higher teaching level and academic level ,this will urge the teachers to improve their own knowledge structure and professional level to ensure the sustainable development of quality courses and teaching quality project.Therefore, it is quite necessary to build a stable adult education teaching team, the team should consider not only the knowledge, age and professional title structure, but also the teaching practice, training and experiment, guidance and answering and graduation design. And giving full play to the role of the professor and academic leaders and passing the teaching philosophy, teaching methods, academic attainments on young teachers are important equally.

The teaching team put adult education courses construction as the main target and task-oriented.It can make the quality of teaching and the effect of teaching improve apparently. And 
a good education teaching team must have 4 basic characteristics as follows: (1) Clear goal of the teaching construction. The teaching team should put the specialty construction, curriculum construction and teaching base construction as the core, and then carry out research and reform revolving the goal. (2)Team members with complementary advantages. An optimized team structure is conductive to cooperation and complementary advantages between members. Also it is good for the development of team spirit and team members; (3) The distinctive team spirit. Team members can form team cohesion by cooperation under the guidance of common goal and value; (4)The clear direction of teaching reform and expected results. The direction of reform can be a link in the teaching process optimization or a project optimization,the teaching effect includes reform and innovation of teaching content,methods and means, and all of them can improve the quality of teaching at last.[3] So the construction of teaching team should focus on the four basic characteristics.

\section{The construction of teaching material}

Compared to students,adult students usually own rich practical experience.It means that they need more suitable curriculum. Therefore, the selection and construction of adult teaching materials must be fit for the situation. Adult education course teaching materials should be a series of excellent textbooks . Course instructors can write their own,also can choose the national excellent textbooks and foreign original teaching materials. Meanwhile the school should encourage the teachers to write textbooks with organic combination of various media according to the knowledge structure of students and the actual requirement of local enterprises. Teaching materials should be closely around the school running orientation,be adapted to the development trend of modern higher education, and follow the higher education law. It also should reflect the advanced ,scientific, innovative and systematic eduction idea, and reflect the school subject characteristics and discipline level.As the same time, the reform achievement of teaching content and curriculum system in twenty-first century and the latest theory of academic research should be reflected fully, and then the teaching materials can be recognized by theorists and practitioners.

\section{The construction of teaching content}

Adult education courses should put the construction of teaching content as the core. According to the demand of the times and the modern education idea,it needs pay attention to the systemic,scientific and advanced of teaching content when putting the latest achievements and scientific research knowledge into the teaching content.Excellent course construction can promote the reform of teaching content, the formation of the new teaching content system and the improvement of the quality of talents. In the selection of course content, the students' knowledge structure, ability and quality training must be considered.And it is quite important to give an accurate positioning course status and role in the process of talent training and to handle the relationship between the course construction and reform. The teaching content of courses should be advanced and can reflect the disciplines of the latest scientific and technological achievements. At the same time,widely absorbing domestic and foreign advanced experience of teaching and actively integrating outstanding teaching achievements reflect the new requirement for the development of society, politics, economy, science and technology. For adult students, it is necessary to do the appropriate addition and subtraction of the curriculum content: addition is to increase the practical teaching contents, on the contrary, subtraction is the reduction theory teaching. Through practical teaching ,students' practical ability and innovative ability can be trained and improved .

\section{Practice analysis of HRM high-quality curriculum construction of adult education}

In March 2012, the course of human resource management was awarded by Adult Education Department.So in order to ensure the implementation of the construction of excellent courses, we did more work on teaching team,teaching contents and teaching methods. Through practice, our 
work has been a widely acclaimed by students, besides, it also provided good experience for the construction of other distinctive professional courses .

The lecturer as well as the author organized a cooperative teaching team under the support of school before teaching.This team consists of four teachers containing the three generations.One of them make course planning,one of them is responsible for gathering teaching material,and others are responsible for teaching for students.Considering the particularity of adult education,the team also invited some professionals out of school,such as human resources directors from () and Changzhou salary and welfare management to give lessons.By team teaching,members from different level can be inspired and supplied each other,so as to realize the communication and crash of wisdom and maximize the function of the team.Generally speaking, it can leads the teaching to positive development orbit.

According to the character of HRM content,the curriculum points can be modular.By reducing units and adjusting combinations, the teaching content can be updated and adjusted.Trough the analysis on the program mentioned above,the systemic and integrity of teaching model will be broken through.And it will be more targeted.Meanwhile,the units can be combined flexibly according to the characteristic of teachers, so as to realize the matching of HR.

In the selection of teaching materials, choose a suitable teaching course and make a list of the reference books to guide the students to read advanced textbooks and references and learn the forefront of HRM revolving around the teaching objectives are benefited to students;during the process of teaching,the lecturer can use heuristic teaching and interactive teaching to stimulate students' learning interest and initiative.Meanwhile,he should pay attention to his teaching way such as case study,collective discussion and scene simulation. All of these can improve the students' ability to get command of HRM knowledge and apply theoretical knowledge flexibly ; about the teaching means, human resources teaching methods are more flexible.Electronic courseware, electronic lesson plan, multimedia and teaching laboratory etc. are applied positively, ultimately all kinds of teaching sources can be shared. By classroom teaching, after-school disambiguation and network real-time answering, the teaching effect is increased greatly.In addition, the targeted tutoring is carried out to help students get through the national HRM qualification examination from grade one to grade four.

Adult Education Department developed a targeted management measures according to the actual situation of excellent courses and summed up a lot of management experience about funds safeguard, process control and monitoring result. What inspired us was that a group of outstanding adult students graduate successfully with our efforts.And some of them wrote many excellent thesis, some of them got through the national human resources qualification test , and the others played a key role in the human resources work.

\section{Conclusion}

The real adult education courses needs stand the double test of practice and time, so it is necessary to reflect the sustainability of excellent courses and the application of adult education.There are two kinds of factors affecting the process of adult education construction. One is internal factors including construction of teaching content,platform construction of course and construction of teaching team; the other is external factors including the support of the country,the school environment protection and the recognition of scholars. Only when the internal factors combined with the external factors, adult education courses can be truly named excellent course. Although,Hohai University (Changzhou campus) has made certain achievements in teaching human resource management, the opportunities that students communicate with entrepreneurs and practice in enterprises still needs to be strengthened because of the financial and time constraints and the lack of practice teaching link.In addition, the extended data and web database of this courses remain to be perfect . 


\section{Acknowledgements:}

Supported Partly by Special Funding of Adult education curriculum reform

\section{References:}

[1] Liu Liquan, Ding lei. Course overview on the construction of excellent course [J]. University Education Science,2010 (5) :34-37.

[2] Yuan Shuqi, Wang Xiaowen. Talk about the course function and sustainable construction [J]. Chineses University Education,2009 (2) :48-50.

[3] Chen Shipin, Peng Yao. Construction and management of teaching team in College.[J]. Journal of Chongqing Institute of Technology, 2008, 22(6):152-157.

[4]Dong Yubo. Research on the construction of university level courses system [J]. Journal of Liaoning Police College, 2007 (5) :86-88.

[5] Peng Yu. the role and the subsequent construction of excellent courses [J]. Journal of Inner Mongolia Finance and Economics College, 2007(7):69-72. 